\title{
Fejlettség és tudáshasznosítás mint emberi jog
}

\section{CSATH MAGDOLNA ${ }^{1}$}

A cikk az emberi fejlettséget mint emberi jogot vizsgálja különböző szempontok szerint. Különbséget tesz az emberi fejlettséghez való hozzájutás joga és a tudás, valamint a képességek használatának lehetösége mint emberi jog között. Az emberi fejlettséget irodalmi áttekintés segítségével mutatja be, különös hangsúlyt fektetve az ENSZ humán fejlettségi indexére (HDI). Azt a következtetést vonja le, hogy egyrészröl az egyénnek joga kell, hogy legyen a fejlettség lehetö legmagasabb szintjének elérése, másrészröl, hogy ez egyben gazdasági érdek is. A gazdaság és a társadalom ugyanis csakakkor tud fejlödni, ha jelentôs humán vagyonnal, jól felkészült, egészséges lakossággal rendelkezik, és a korszerü társadalmi gazdasági szerkezet létrehozásával megteremti a humán vagyon hatékony foglalkoztatásának feltételeit.

Kulcsszavak: emberi fejlettség, humán erőforrások (vagyon), tudásalapú gazdaság, regionális eltérések, nem megfogható beruházások

\section{Development and Knowledge Utilisation as a Human Right}

This article analyses human development as a human right from different perspectives. It differentiates between the right for acquiring human development, and the right for the opportunity to capitalise on knowledge and skills. The article examines human development based on a comprehensive literature survey with special focus on the UNDP HDI (Human Development Index). It concludes by emphasising the importance of securing the rights for achieving the highest possible development level for all citizens pointing out that actually this is also an economic interest. The economies and societies can only develop sustainably if a considerable human wealth, well-educated and healthy population is available, and the efficient deployment of these resources is facilitated by modern knowledgebased economic structures.

Keywords: human development, human resources (wealth), knowledgebased economy, regional inequalities, brain drain, intangible investment

1 Kutatóprofesszor, Nemzeti Közszolgálati Egyetem; kutatásvezető, Pázmány Péter Katolikus Egyetem, e-mail: csath.magdolna@uni-nke.hu 


\section{Bevezetés}

A fejlettséget sokféleképpen értelmezhetjük. Beszélhetünk gazdasági fejlettségről, az oktatási és egészségügyi rendszer fejlettségéről, a közlekedési hálózat fejlettségéről. A fejlettséget kapcsolatba hozhatjuk a fejlődéssel is, amelyen általában olyan folyamatot értünk, amely előnyös változást, javulást eredményez egy rendszerben. Esetenként a gazdasági növekedést is fejlődésnek értelmezik, feltéve, hogy az nem tesz kárt más rendszerekben, például a környezetben. A gazdaságban beszélünk alulfejlett vagy kevéssé fejlett országokról, amikor is a fejlettség szintjét az egy főre jutó megtermelt új érték (GDP/fö) nagysága alapján határozzuk meg.

A Nemzetközi Valutalap (IMF) fejlődő, feltörekvő és fejlett országokról beszél, a V4-ek közül Magyarországot és Lengyelországot sorolja a fejlődő, feltörekvő országok csoportjába. Csehországot és Szlovákiát pedig már fejlett országnak tekinti. A csoportosítás azonban kizárólag gazdasági szempontok alapján történik, közöttük is a bruttó hazai termék (GDP), illetve az egy före jutó bruttó hazai termék növekedése játszik fontos szerepet. A Világbank az országokat magas, felső-közepes, alsó-közepes és alacsony jövedelmủ országokra osztja, a megkülönböztetés alapja ez esetben a jövedelmi szint, az egy före jutó nemzeti jövedelem (GNI/fő). Érdemes megemlíteni az ENSZ fenntarthatósági céljait is, amelyek a fejlettséget már sokkal tágabban értelmezik. Vizsgálják például a területi egyenlőtlenségeket, a rendelkezésre álló munkahelyek minőségét, a nemek közötti egyenlőség mértékét és a jó egészségügyi ellátáshoz jutás lehetőségeit. A fejlettség gazdasági tényezői mellett az ENSZ emberi fejlettségi indexe kitér két fontos emberi fejlettségi szempontra, az oktatási színvonalra és az egészségi állapotra. Az emberi fejlettség indexét (Human Development Index, HDI) az ENSZ 1990 óta vizsgálja, állandóan finomítva az alkalmazott módszertant. A 2020-ban megjelent tanulmány ${ }^{2}$ a korábban vizsgált egy före jutó GNI, születéskor várható élettartam és iskolázottság mellett már a gazdaságok környezeti hatásait is vizsgálja. Egy 2021. évi tanulmánya ${ }^{3}$ pedig újabb szempontot, az egyenlőtlenségeket is górcső alá veszi.

Az ENSZ az országokat nagyon magas, magas, közepes és alacsony emberi fejlettségű csoportokra osztja. 2020-ban a nagyon magas fejlettségi csoportban a vizsgált 189 országból 66 szerepelt. Közöttük Csehország a 27., Lengyelország a 35., Szlovákia a 39. és Magyarország a 40. helyen található. Az első öt helyet Norvégia, Írország, Svájc, Hongkong és Izland foglalja el. A nagyon magas fejlettségű országok indexe a 0-1-es skálán átlagosan 0,898, az alacsony fejlettségủeké pedig 0,513. A magyar érték 0,854 . Erre az elemzésre a későbbiekben még visszatérünk. Megállapítható, hogy az elemzések nagyon hasznosak, azonban kiinduló szempontjuk elsősorban a gazda-

2 UNDP: Human Development Report 2020. The next frontier: Human development and the Anthropocene. New York, 2020.

3 UNDP-OPHI: Global Multidimensional Poverty Index 2021. Unmasking disparities by ethnicity, caste and gender (2021). 
ság állapota, és nem az egyén, az ember joga a fejlődéshez, fejlettséghez. A továbbiakban arra teszünk kísérletet, hogy a fejlődési lehetőségeket és a fejlettséget az emberek rendelkezésére álló lehetőségként vizsgáljuk meg. Két szempont szerint is vizsgálódunk: egyrészt az egyéni fejlődési lehetőségek, másrészt pedig a tudás, a képességek hasznosíthatósága szempontjából. Végső soron, amint látni fogjuk, gazdasági érdek is, hogy az emberi fejlődés lehetősége rendelkezésre álljon mindenki számára, illetve, hogy minden ember számára adódjon arra lehetőség, hogy tehetségét, képességeit kifejthesse, hasznosíthassa. Az emberi fejlödést úgynevezett nem megfogható (angolul intangible) befektetésnek tekintjük, amely az egyén oldaláról növeli nemcsak a gazdasági értelemben vett jólétet, hanem az életminőséget, a „jól-létet” is. Másrészről hozzájárul a társadalmi tőke, a társadalom immunrendszere, válságokkal szembeni ellenállóképessége erősödéséhez.

\section{Irodalomfeldolgozás}

Az emberi fejlődés, kiteljesedés egyik ismert kutatója Maslow, ${ }^{4}$ amerikai pszichológus az emberi szükségletek több szintjéről ír. Azt bizonyítja, hogy az emberi szükségletek nem elégíthetők ki csak a mindennapi igények biztosításával. Az emberek igénylik az együttműködést, a szeretetet, elismerést és a barátságot is. Ezen túlmenően annak is örülnek, ha képességeiket fejleszthetik, tudásukat hasznosíthatják, kreatív, innovatív feladatokat oldhatnak meg. A humán tőkeelmélet híres képviselője, Schultz ${ }^{5}$ arra figyelmeztet, hogy az ember megbecsülése, az emberi fejlődés támogatása nélkül a fizikai tőkebefektetések értéktelenné válnak. Ezért nemcsak joga van az egyénnek a személyes fejlődéshez, hanem az feltétele is a gazdasági eredményeknek. Mások szerint a tudáshoz, képességhez való hozzájutás emberi jog, amelynek gyakorlása nemcsak az egyénnek, hanem a közösségnek is értéket teremt. Az ENSZ 1986-ban fogadta el a fejlődéshez való jogról szóló nyilatkozatot hangsúlyozva, hogy a fejlődés nemcsak gazdasági, hanem társadalmi és egyéni kérdés is. A dokumentum - egyéb témák mellett - hangsúlyozza a tudáshoz, képzéshez való jog fontosságát. A nyilatkozatot $^{6}$ 1986-ban 146 ország írta alá, az USA ellene szavazott, és Dánia, Finnország, a Német Szövetségi Köztársaság, Izland, Japán, Svédország, Izrael és Nagy-Britannia tartózkodott. A nyilatkozat érdeme, hogy nemcsak a jogot hangsúlyozza, hanem azt is, hogy annak érvényesítéséhez az államoknak meg kell teremteniük a feltételeket.

A Nobel-díjas Amartya Sen ${ }^{7}$ is a fejlödésről mint emberi jogról ír, és összefüggésbe hozza a fejlődéshez való jogot a fenntartható gazdasággal és a jól-léttel. Sen arra is rámutat, hogy a gazdasági fejlődés nem jár feltétlenül együtt humán fejlődéssel. Ennek

4 Abraham Maslow: A Theory of Human Motivation. Psychological Review, 50. (1943), 4. 370-396.

5 Theodore W. Schultz: The Economic Importance of Human Capital in Modernization. Education Economics, 1. (1993), 1. 13-19.

6 United Nations: United Nations Declaration on the right to development. UNGA Res. 41/128. December 1986.

7 Amartya Sen: Development as Freedom. New York, Anchor Books, 2000. 
okaként azt említi, hogy a gazdasági fejlődést mérő GDP-mutató úgy is növelhető, hogy közben az emberek életminősége romlik. Ezt bizonyítja azon jelentős gazdasági növekedést felmutató országok példája, amelyekben a várható élettartam, a GDPvel mért jó gazdasági eredmények ellenére alacsony. A várható élettartam az emberi fejlettség egyik fontos jellemzője. Növeléséhez erős egészségügyi rendszerre, egészséges környezetre és az emberi képességeket hasznosító, jó minőségü, az egészségre nem ártalmas munkahelyekre van szükség. A fejlődéshez való jog érvényesülését gátolják a nagy regionális különbségek elsősorban akkor, ha ezek nehezítik a tudáshoz és az egészséghez való hozzáférést. Ezzel kapcsolatban érdekes elemzés található az Európai Unió (EU) egyik friss tanulmányában. Az Európai Társadalmi Haladás Index (European Social Progress Index) ${ }^{8}$ regionális szinten vizsgálja a humán társadalmi haladást. A vizsgálatban gazdasági adatok nem szerepelnek, 55 egyéb mutató alapján hasonlítja össze az EU 242 régiójának helyzetét. A vizsgálat logikai felépítése Maslow hierarchiáját követi, de épít Sen gondolataira is. Így elemzi az alapvető humán szükségletek kielégítettségét, a jól-lét, életminőség megalapozottságát és az emberek számára rendelkezésre álló lehetőségeket. A lehetőségeket négy területen vizsgálja. Ezek a személyes jogok, a szabadság és választási lehetőség, a tolerancia és befogadás, valamint a magasabb szintű tudáshoz való hozzáférés lehetősége. Általános rangsor nem készül, így csak a 0-100 közötti értéken (100 a legjobb) való elhelyezkedés alapján lehet összehasonlítani az egyes régiók helyzetét. Az országokon belüli regionális különbségeket különösen jól mérik az EU-s átlag, a főváros és a legkevéssé fejlett régió adatainak eltérései. Magyarország esetében Budapest adatai - a környezeti mutatók, különösen a levegő minősége kivételével - az EU-s átlag közelében vannak. Viszont például Észak-Magyarország adatai az EU-s átlagtól és a budapesti értéktől is jelentősen el vannak maradva. Feltűnően nagy különbség éppen az emberi fejlettség legfontosabb eleménél, a tudáshoz jutás lehetőségénél található. Ez az adatok értéke szempontjából azt jelenti, hogy az EU-s társadalmi haladás átlagértéke a 0-100-as skálán 66,7, Budapesté 63,6, Észak-Magyarországé pedig 50,9. A lehetőségek alindex értéke az EU-ban átlagosan 57,5, Budapestre 55,3, és Észak-Magyarországra 38,8. Említsük még meg az alap- és magasabb szintű tudáshoz jutási lehetőség index értéket is! Az EU-s átlag 73,9 az alapszintű és 57,1 a magasabb szintű tudáshoz jutás esetén. A budapesti értékek 83,4 és 72,3. Mindkettő jelentősen meghaladja az EU-s átlagot. Észak-Magyarországra pedig a két érték 54,6 és 29,4. Mindkét érték rosszabb, mint az EU-s átlag, és jelentősen marad el a budapesti értékektől is.

A nagy regionális különbségek, ahogyan arra a társadalmi fejlettségi index kutatás rámutat, gátolják, hogy az emberek kifejthessék képességeiket, és végső soron rontják az országos fejlettségi szintemelés esélyeit is. Korunkban az emberi fejlettség kiteljesedésének fontos eszköze az infokommunikációs eszközökhöz és tudáshoz való hozzáférés lehetősége. Gondoljunk csak arra, hogy mekkora tudáslemaradást jelenthetett az infrastruktúra és a tudás hiánya azon családok gyermekei számára, akik a pandémia 
alatt nem tudtak bekapcsolódni az online oktatásba. Az EU elemzésében az infokommunikációs hozzáférhetőségre Budapest 81,9, Dél-Alföld 68,6, Észak-Magyarország 68,4, Észak-Alföld 69,3, Dél-Dunántúl 69,2 pontot kapott. Az EU-s átlag 75,7. A regionális különbségekre később még visszatérünk.

A humán fejlettség, illetve az annak megszerzését lehetővé tevő környezet nemcsak az egyén, hanem az egész közösség számára fontos, mivel erősíti az összefogást, a társadalmi tőkét. A társadalmitőke-kutatások sokrétűek, de közös következtetésük, hogy a társadalmi tőke erőssége nemzetmegtartó, válságok esetén a válságálló-képességet erősítő és végső soron a fejlődést támogató társadalmi jellemző. Christoforou ${ }^{9}$ empirikus kutatásokkal igazolja, hogy az erős összetartozás, az erős társadalmi tőke jó hatással van az emberi fejlődésre, támogatja, ösztönzi a tanulást, a képzésekben való részvételt. Widdows, Ha és $Z_{h}{ }^{10}$ az egészségügyben végzett vizsgálataik alapján arra a következtetésre jutnak, hogy a társadalmi tőke erőssége hozzájárul a tudásszint bővüléséhez, amely támogatja az emberi fejlődést. A társadalmi tőke azáltal is erősíti a tudásszintet, hogy az erős bizalmi szint miatt természetessé válik a tudásmegosztás. A társadalmitőke-kutatások arra is bizonyítékot találtak, hogy az emberi fejlődés egy másik fontos területe, az egészség és a várható élettartam is összefüggésbe hozható a társadalmi tőkével. Statisztikai adatok is bizonyítják, hogy az erős társadalmi tőkéjü országokban, mint például a skandináv országokban jó az átlagos egészségi állapot, és magas a várható élettartam. Viszont a nagy regionális különbségek gyengítik a társadalmi tőkét, és ezáltal az emberi fejlődésnek nemcsak a tudás-, hanem az egészség elemét sem támogatják. ${ }^{11}$

Ezt a témát elemezte Kunitz, ${ }^{12}$ aki azt találta, hogy a társadalmi tőke erőssége jó hatással van az emberi fejlődés egészség elemére, bár a hatás erősségét a helyi kulturális viszonyok is befolyásolják. Ohno ${ }^{13}$ kutatásokra alapozva elemzi, hogy miért fontos a tudás a helyi fejlődéshez. Tágabb összefüggésbe helyezve a témát arra mutat rá, hogy a nemzetek versenyében tartós gazdasági-társadalmi sikerre csak az az ország számíthat, amelyik lehetőséget biztosít arra, hogy a lakosság folyamatosan tanulhasson, ezáltal egyénileg, de a közösség érdekében is fejlődhessen, továbbá a tudását hasznosíthassa is. Ebből az is következik, hogy a mindenkori kormányzásnak feladata a humán vagyon állandó erősítése, vagy ahogyan Ohno fogalmaz, a fizikai vagyon mellett a humán vagyon felhalmozása, olyan gazdaságpolitikai gyakorlat megvalósítása, amely biztosítja a tudás hasznosítását és állandó újrateremtését.

9 Asimina Christoforou: Social Capital and Human Development: An Empirical Investigation Across European Countries. Journal of Institutional Economics, 6. (2010), 2. 191-214.

10 Jing Zhao - Sejin Ha - Richard Widdows: The Influence of Social Capital on Knowledge Creation in Online Health Communities. Information Technology and Management, 17. (2015), 4. 311-321.

11 Eleonora P. Uphoff et al.: A Systematic Review of the Relationships between Social Capital and Socioeconomic Inequalities in Health: A Contribution to Understanding the Psycholosocial Pathway of Health Inequalities. International Journal for Equity in Health, 12. (2013), 54.

12 Stephen J. Kunitz: Social Capital and Health. British Medical Bulletin, 69. (2004), 1. 61-73.

13 Kenichi Ohno: Learning to Industrialize. From Given Growth to Policy-Aided Value Creation. London - New York, Routledge, 2013. 12; Kunitz (2004): i. m. 
Maslowra gondolva nyilvánvaló, hogy az életminőséget, a boldogságszintet is javítja, ha az emberek fejlődhetnek, képességeiket gazdagíthatják és hasznosíthatják. A boldogságszintet a Világboldogság tanulmány méri. ${ }^{14}$

Az elemzők sok szempont szerint vizsgálják a boldogságot, közülük több az emberi fejlődési lehetőségekkel is kapcsolatba hozható. A 2020. évi tanulmány sorban a nyolcadik. Az elemzés vizsgálja a környezet állapotát, a társadalmi viszonyokat, beleértve a korrupció mértékét, a társadalmi tőke erejét, de kitér az egészségi állapotra és a várható élettartamra is.

A 153 országot tartalmazó listát 2020-ban Finnország vezeti, második Dánia, harmadik Svájc.

Ausztria a 4., Csehország a 19., Szlovákia a 37., Lengyelország a 43., és Magyarország az 53. helyen van. A tanulmány felhívja a figyelmet arra, hogy a nagy anyagi és társadalmi különbségek rossz hatással vannak a boldogság szintjére. A városokra jellemző boldogságszintet 186 város esetén vizsgálják. A legboldogabbnak Helsinkit találták. Bécs a 29., Prága a 44., Pozsony az 54., Bukarest a 81., Budapest pedig csak a 103. helyen található. Budapestet megelőzi Belgrád, Moszkva és Ankara is.

A felmérés alapja a lakosok kikérdezése volt. Az elemzés fontos következtetése, hogy a jól-lét több mint az anyagiak, vagyis a jólét. A fejlődési, tanulási lehetőségek, az egészségmegőrzés lehetősége, a várható élettartam növekedése és a társadalmi öszszetartozás, társadalmi tőke ereje teszi igazán boldoggá az embereket. Ezeken a területeken vezetnek a skandináv országok. Tegyük azonban hozzá, hogy visszahatás is kimutatható: a fejlődési lehetőség és a társadalmi tőke erőssége visszahat a gazdasági eredményekre, a versenyképességre is. Ezért találjuk ott a skandináv országokat a versenyképességi listák elején. Végül ejtsünk néhány szót a bruttó nemzeti boldogság indexről! A bruttó nemzeti boldogság fogalom Bhutánból származik, ahol az uralkodó elvetette, hogy gazdasági eredményekkel, például a GDP-vel vagy az egy főre jutó GDP-vel mérje országa teljesítményét. Bevezette a bruttó nemzeti boldogság (Gross National Happiness, GNH) mutatót, amely a lakosság kollektív boldogságát, jól-létét méri. Célja, hogy ennek a mutatónak értéke folyamatosan javuljon. Ezt a célt a nemzeti alkotmányba 2008. július 18-án bele is foglalták. A GNH-mutató négy területen méri az elért eredményeket.

Ezek:

- a fenntartható és igazságos társadalmi-gazdasági fejlődés;

- a környezet védelme, megörzése;

- a nemzeti kultúra védelme és megőrzése;

- a jó kormányzás.

A négy területet elemző mutatók között megtaláljuk a jó egészséghez és a legjobb tudáshoz jutás jogát, a közösségek erejét, vitalitását, amelyet társadalmi tőkeként is értelmezhetünk és a különbségek csökkentését. A nemzetközi források arra hívják fel

14 John Helliwell - Richard Layard - Jeffrey D. Sachs (szerk.): World Happiness Report. New York, Sustainable Development Solutions Network, 2019. 
a figyelmet, hogy valószínủleg ennek a különleges kormányzati szemléletnek köszönhető, hogy Bhután nagyon jól kezelte a pandémiát is. A bhutáni filozófiát így lehetne összefoglalni: a GNH-index a fejlődésről szól, világos, emberközpontú értékrend mentén.

\section{Nemzetközi fejlettségi elemzések: gazdasági vetületek}

\subsection{Az emberi fejlettségi index alakulása}

Az 1. táblázatban az emberi fejlettségi index értékének változását látjuk 1990-ről 2019-re a V4-ek és Ausztria esetén.

1. táblázat: Az emberi fejlettségi index értékének változása nemzetközi összehasonlításban (1990-2019) Forrás: UNDP: Human Development Report 2020. The next frontier: Human development and the Anthropocene. New York, 2020.

\begin{tabular}{|l|c|c|c|c|c|c|c|c|c|c|c|}
\hline Ország & 1990 & 2000 & 2010 & 2014 & 2015 & 2017 & 2018 & 2019 & $\begin{array}{l}\text { Érték- } \\
\text { változás } \\
\text { 1990-ról } \\
\text { 2019-re }\end{array}$ & $\begin{array}{l}\text { Pozíció- } \\
\text { változás } \\
\text { 2014-ról } \\
\text { 2018-ra }\end{array}$ & $\begin{array}{l}\text { Átlagos } \\
\text { évi } \\
\text { javulás } \\
(\%)\end{array}$ \\
\hline Magyarország & 0,708 & 0,772 & 0,831 & 0,838 & 0,842 & 0,846 & 0,850 & 0,854 & 0,146 & 1 & 0,65 \\
\hline Ausztria & 0,803 & 0,847 & 0,904 & 0,913 & 0,915 & 0,919 & 0,921 & 0,922 & 0,119 & 0 & 0,48 \\
\hline Csehország & 0,738 & 0,804 & 0,870 & 0,888 & 0,891 & 0,896 & 0,898 & 0,900 & 0,162 & -1 & 0,69 \\
\hline Lengyelország & 0,718 & 0,790 & 0,840 & 0,858 & 0,863 & 0,873 & 0,877 & 0,880 & 0,162 & 0 & 0,70 \\
\hline Szlovákia & 0,741 & 0,765 & 0,831 & 0,847 & 0,850 & 0,855 & 0,858 & 0,860 & 0,119 & -2 & 0,51 \\
\hline
\end{tabular}

A magyar érték, a folyamatos javulás ellenére, 1990-ben és 2019-ben is a legalacsonyabb. Ennek oka a javulás üteme: mivel mi indultunk a legrosszabb pozícióból, ezért gyorsabban kellene ahhoz haladnunk, hogy ledolgozzuk lemaradottságunkat. Ehhez azonban kevés volt a 0,146-os indexérték-javulás: csupán arra volt elég, hogy megközelítsük Szlovákiát. Például mivel Csehország gyorsabban javította pozícióját, ezért a közöttünk lévő távolság 1990-ről 2019-re 0,03-ról 0,046-ra nőtt. Meg kell jegyeznünk, hogy bár a HDI-index nagyon fontos emberi fejlettségi állapotokat vizsgál, mégsem ad átfogó képet a lehetőségekről. Hiszen javulhat az iskolázottsági szint, de ha a gazdaság szerkezete nem teszi lehetővé a megszerzett tudás hasznosítását, akkor a tudás kihasználatlan marad, és ahogyan azt idézni szokták, a gép akkor kopik, ha használják, a tudás pedig akkor, ha nem használják. Ezért a tudás elkopása együtt jár a fejlettségi szint csökkenésével. A tudáshasznosítási lehetőséget többféleképpen is lehet mérni. Az egyik lehetőség a foglalkoztatási szerkezet vizsgálata. 


\subsection{Foglalkoztatási adatok nemzetközi összehasonlításban}

A 2. táblázatban Magyarország és öt fejlett ország foglalkoztatási adatait látjuk. Az adatok az emberi fejlődési lehetőség, illetve a tudáshasznosítás szempontjából érdekes jellemzőkre világítanak rá.

\section{2. táblázat: Foglalkoztatási adatok nemzetközi összehasonlításban, 2020, (\%)}

Forrás: a szerző szerkesztése az Eurostat 2021. szeptember 10-ei adatai alapján

\begin{tabular}{|ll|l|l|l|l|l|}
\hline Ország & & $\begin{array}{l}\text { A feldolgozó- } \\
\text { iparban } \\
\text { alacsony } \\
\text { tudásigényű } \\
\text { területen fog- } \\
\text { lalkoztatottak }\end{array}$ & $\begin{array}{l}\text { A szolgálta- } \\
\text { tásban magas } \\
\text { tudásigényű } \\
\text { területeken } \\
\text { foglalkoz- } \\
\text { tatottak }\end{array}$ & $\begin{array}{l}\text { Szakmai, } \\
\text { tudományos } \\
\text { és műszaki } \\
\text { területen } \\
\text { foglalkozta- } \\
\text { tottak }\end{array}$ & $\begin{array}{l}\text { Egészség- } \\
\text { ügyben } \\
\text { és szociális } \\
\text { munkában } \\
\text { foglalkoz- } \\
\text { tatottak }\end{array}$ & $\begin{array}{l}\text { Szolgál- } \\
\text { tatásban } \\
\text { foglalkoz- } \\
\text { tatottak }\end{array}$ \\
\hline Magyarország & $(40,42)$ & 6,7 & 35,6 & 4,2 & 7,2 & 63 \\
\hline Ausztria & $(18,19)$ & 4,6 & 39,4 & 4,9 & 10,9 & 71 \\
\hline Németország & $(6,5)$ & 5,1 & 49,2 & 5,3 & 13,0 & 71 \\
\hline Dánia & $(10,3)$ & 3,7 & 54,6 & 6,0 & 18,1 & 79 \\
\hline Finnország & $(11,11)$ & 4,0 & 35,5 & 7,9 & 16,3 & 74 \\
\hline Svédország & $(7,2)$ & 2,8 & 47,5 & 8,9 & 15,0 & 79 \\
\hline EU-átlag & - & 5,7 & 40,0 & 5,5 & 10,8 & 70 \\
\hline
\end{tabular}

A fejlődést segíti, ha a gazdasági szerkezet olyan, hogy igényli a tudást, ha sok olyan ágazat van, amely magasabb szakértelmet igénylő munkahelyeket teremt.

A 2. táblázatban azokat az országokat szerepeltetjük, amelyek jóval előttünk vannak a korábban említett HDI- (humán fejlettségi index) mutató ${ }^{15}$ alapján készült sorrendben. A pozíciójukat az országnév mellett zárójelben az első érték mutatja.

Az összes foglalkoztatottból a feldolgozóiparban alacsony tudást igénylő munkahelyen Magyarországon dolgoznak a legtöbben. Ez azt is jelentheti, hogy mivel nincs elegendő ,jó minőségü" munkahely, ezért a munkavállalók között vannak olyanok, akik magasabb tudásigényủ munkát is el tudnának végzeni, ha lenne olyan. Ez pocsékolás a legfontosabb nemzeti vagyonelemmel, az emberi képességgel.

Ennek a helyzetnek az előfordulását igazolta egy 600 külföldön dolgozó fiatal körében végzett kutatás ${ }^{16}$ amely azt találta, hogy a külföldi munkavállalás egyik oka éppen az volt, hogy nem találtak a jól felkészült fiatalok szakmailag igényes munkahelyet, illetve elégedetlenek voltak a magyarországi munkaviszonyokkal.

15 UNDP (2020): i. m.

16 Pálfi Nóra: A külföldi munkavállalás hazai versenyképességre gyakorolt hatásainak vizsgálata. In Csath Magdolna (szerk.): Versenyképességi dilemmák a digitalizáció és robotizáció korában. Budapest, Dialóg Campus, 2020. 233-260. 
Úgy is fogalmazhatnánk, hogy a hazai munkakörülmények nem tették lehetővé számunkra, hogy elérjék a Maslow-i hierarchia csúcsát, kiteljesíthessék és hasznosíthassák tudásukat, képességeiket. A mintában 52,7\% volt a felsőfokú végzettségủek aránya, ami nyilvánvalóan nagy veszteség, hiszen ha ezek a felsőfokú végzettségüek itthon dolgoznának, akkor jelentősen járulhatnának hozzá a hazai új értékteremtéshez, és ezzel a magyar gazdaság versenyképességének javulásához. De nemcsak a feldolgozóiparban nincs elegendő nagy tudást igénylő munkahely. A táblázat második oszlopában azt látjuk, a magas tudásigényű szolgáltatási munkahelyeken is a munkavállalók csupán 35,6\%-a dolgozik. Ez az érték a HDI-rangsorban jóval előttünk lévő országokban - Finnország kivételével - sokkal magasabb. A szakmai, tudományos és müszaki területeken foglalkoztatottak aránya is nálunk a legalacsonyabb, pedig ezek nagy tudást igénylő, igényes munkahelyek.

Az emberi fejlettség szempontjából kulcsfontosságú az egészségügyi foglalkoztatás és a társadalmi problémákat megoldani segítő szociális munkahelyek, illetve az ezeken dolgozók száma. A negyedik oszlop azt mutatja, hogy ezeken a területeken Magyarország nagyon le van maradva a többi ország mögött. Az EU-s átlagnál 3,6, a dán értéknél 10,9 százalékponttal rosszabb a magyar érték. Ez a társadalmi tőkét is gyengítő tényező. Az utolsó oszlop a szolgáltatási szektor foglalkoztatását mutatja a teljes foglalkoztatáson belül. Az EU-s átlagtól 7\%-kal lemaradva Magyarország van az utolsó helyen a vizsgált országok között. Gazdasági elemzések rámutatnak, hogy a szolgáltató szektort, elsősorban annak nagy hozzáadott értéket teremtő ágazatait a jó munkahelyek és a nagy hozzáadottérték-előállítás jellemzi, ezért a humán fejlettségi index és a versenyképesség javulásához egyaránt hozzájárulnak.

Végül említsük meg, hogy a versenyképességi pozíció, amelyet az országok melletti zárójelben a második érték jelez, szintén összefüggést mutat a nagyobb értéket teremtő és tudást igénylő munkahelyeken dolgozók arányával, de a HDI-indexre elért pozícióval is. Levonhatjuk azt a következtetést, hogy az egyéni fejlődést és a nemzeti és a gazdasági versenyképességet egyaránt befolyásolja a gazdasági szerkezet, a magasabb tudást igénylő munkahelyek aránya. Ennek még olyan kihatásai is vannak, hogy ha nincs elegendő igényes munkahely, akkor azok a magasan képzett szakemberek, akik nem találnak megfelelő munkahelyet, elhagyhatják az országot, rontva a versenyképesség javításának esélyeit, egyben csökkentve a nemzeti vagyont. Az emberi fejlődés lehetőségeit, ahogyan arra a boldogságindexek is utalnak, befolyásolják a tudáshoz jutás, illetve a tudáshasznosítás regionális jellemzői is.

\subsection{Regionális jellemzök}

A 3. táblázatban a V4-ek és Ausztria, valamint az öt főváros GDP/fő mutató (vásárlóerő-paritáson) mért adatait látjuk három évben. Ezenkívül ugyanezen három évben látjuk az adott évben legkevésbé fejlett régió (2021-ben összesen 242 régió van) adatát. Az összevetés alapja a GDP/fö mutató az árkülönbségeket kiküszöbölő vásár- 
lóerő-paritáson mérve. Az értékek az EU27 átlagát 100-nak tekintve mutatják meg az EU-átlaghoz való felzárkózottság szintjét.

\section{3. táblázat: Regionális GDP/fó érték (vásárlóerö-paritáson) az EU27 átlagához viszonyítva}

Forrás: a szerzó szerkesztése az Eurostat 2021. július 27-ei adatai alapján

\begin{tabular}{|c|c|c|c|c|c|c|}
\hline \multirow[t]{2}{*}{ Ország } & \multicolumn{3}{|c|}{ GDP/fö (EU27 = 100) } & \multicolumn{3}{|c|}{$\begin{array}{l}\text { A legalacsonyabb regionális érték, } \\
\text { GDP/fö, }(\text { EU27 = 100) }\end{array}$} \\
\hline & 2010 & 2015 & 2019 & 2010 & 2015 & 2019 \\
\hline Magyarország & 66 & 70 & 73 & 39 & 45 & 47 \\
\hline Csehország & 84 & 89 & 92 & 63 & 64 & 64 \\
\hline Lengyelország & 63 & 69 & 73 & 44 & 48 & 50 \\
\hline Szlovákia & 76 & 78 & 70 & 51 & 55 & 50 \\
\hline Ausztria & 128 & 131 & 126 & 85 & 91 & 89 \\
\hline Budapest & 144 & 140 & 151 & & & \\
\hline Prága & 192 & 197 & 205 & & & \\
\hline Varsó & 140 & 151 & 160 & & & \\
\hline Pozsony & 189 & 193 & 162 & & & \\
\hline Bécs & 166 & 158 & 149 & & & \\
\hline
\end{tabular}

A V4-ek között országos szinten egyedül Csehország ugrik ki 2019-ben 92\%-os értékével, vagyis azzal, hogy már csaknem elérte az EU27 átlagát. A növekedési sebességet tekintve viszont Lengyelország van az élen 10 százalékpontos bővülési értékével. 2019-ben Magyarország Lengyelországgal együtt másodikként követi Csehországot. Viszont a fővárosok között Budapest rontotta pozícióját. 2010-ben még megelőzte Varsót, de 2019-re sereghajtó lett. Ha a vizsgált országokon belül a legkevésbé fejlett régiók adataira tekinthetünk, akkor azt látjuk, hogy minden vizsgált évben a legkevésbé fejlett régió Magyarországon van. Ez a régió 2010-ben Észak-Magyarország és 2015, 2019-ben Észak-Alföld volt.

Ha a fővárosok és a legkevésbé fejlett régió közötti szakadékot is vizsgáljuk, akkor azt tapasztaljuk, hogy ez 2019-ben Ausztria esetén a legkisebb (Bécs 149, Burgenland 89, különbség 60). A legnagyobb eltérés Csehországban van, de a többi V4-es eltérés is nagyon nagy. Budapest és Észak-Alföld EU27-átlagához viszonyított értéke között 2019-ben 104 százalékpontnyi a szakadék, ami 73,4\%-kal magasabb, mint az osztrák érték. A nagy különbség következménye, ahogyan arra az EU társadalmi fejlettségi index tanulmánya is rávilágít, a kisebb esély az emberi fejlődésre, a tudáshoz, képességekhez való hozzájutás lehet.

Még alaposabb elemzést tesz lehetővé a KSH regionális adatbázisa, amely a magyar országos átlaghoz méri az egyes régiók, illetve megyék egy före jutó GDP-értékét hosszabb időtávon. 
4. táblázat: Egy fóre jutó GDP megyei és régiós bontásban az országos átlag \%-ában Forrás: a szerző szerkesztése a KSH adatai alapján

\begin{tabular}{|c|c|c|c|c|c|}
\hline Régió/megyei & 2000 & 2010 & 2015 & 2019 & $\begin{array}{l}\text { Változás } \\
\text { 2000-ről 2019-re } \\
\text { (százalékpont) }\end{array}$ \\
\hline Budapest régió & 196,5 & 218,8 & 200 & 206,6 & $+10,1$ \\
\hline Pest megye/régió & 82,7 & 87,5 & 83,4 & 79,7 & -3 \\
\hline Fejér megye & 116 & 87,7 & 103,6 & 99,2 & $-16,8$ \\
\hline Komárom-Esztergom megye & 82 & 100,9 & 102,5 & 100,3 & $+18,3$ \\
\hline Veszprém megye & 85,8 & 73,1 & 74,4 & 76 & $-9,8$ \\
\hline Közép-Dunántúl & 96,2 & 86,7 & 93,8 & 92 & $-4,2$ \\
\hline Győr-Moson-Sopron megye & 135 & 121,4 & 130,5 & 113,6 & $-21,4$ \\
\hline Vas megye & 112,3 & 86,6 & 97,6 & 90 & $-22,3$ \\
\hline Zala megye & 86,7 & 86,4 & 81,8 & 75,2 & $-11,5$ \\
\hline Nyugat-Dunántúl & 114,4 & 102,3 & 108,3 & 97,2 & $-17,2$ \\
\hline Baranya megye & 73,5 & 66,7 & 64,3 & 67,9 & $-5,6$ \\
\hline Somogy megye & 69,7 & 63,7 & 62,6 & 64,9 & $-4,8$ \\
\hline Tolna megye & 82,3 & 74 & 75,4 & 76 & $-6,3$ \\
\hline Dél-Dunántúl & 74,4 & 67,5 & 66,5 & 68,9 & $-5,5$ \\
\hline Borsod-Abaúj-Zemplén megye & 63 & 60 & 71,1 & 68,6 & $+5,6$ \\
\hline Heves megye & 70,7 & 68,7 & 71,6 & 77 & $+6,3$ \\
\hline Nógrád megye & 52,3 & 44,4 & 44,6 & 44,3 & -8 \\
\hline Észak-Magyarország & 63,1 & 59,6 & 66,7 & 66,7 & $+3,6$ \\
\hline Hajdú-Bihar megye & 76,5 & 74,8 & 71,2 & 71,3 & $-5,2$ \\
\hline Jász-Nagykun-Szolnok megye & 63,9 & 61,2 & 65,3 & 64,4 & $+0,5$ \\
\hline Szabolcs-Szatmár-Bereg megye & 58,6 & 54,1 & 55,9 & 58,8 & $+0,2$ \\
\hline Észak-Alföld & 66,4 & 63,5 & 63,9 & 64,7 & $-1,7$ \\
\hline Bács-Kiskun megye & 71 & 66,7 & 78,3 & 81 & $+10,0$ \\
\hline Békés megye & 66,7 & 57,8 & 60,8 & 58,9 & $-7,8$ \\
\hline Csongrád megye & 82,1 & 73,8 & 75,3 & 73,7 & $-8,4$ \\
\hline Dél-Alföld & 73,2 & 66,5 & 72,5 & 72,7 & $-0,5$ \\
\hline
\end{tabular}

A 4. táblázatban azt látjuk, hogy összesen két régió (Budapest és Észak-Magyarország), valamint hat megye javította pozícióját, igaz, nagyon egyenlőtlen mértékben. A legnagyobb ugrás Budapesten, Komárom-Esztergom és Bács-Kiskun megyében következett be. De jelentős különbségekre is felfigyelhetünk. Míg Budapest egy főre jutó GDP-je az országos átlag több mint kétszerese (206,6), Nógrád megyéé az országos átlag felét sem éri el $(44,3)$, ráadásul eredményei 2000-hez viszonyítva még 8 százalékponttal romlottak is. Nyilvánvalók tehát a nagy regionális különbségek, amelyek emberi fejlődési lehetőségekben található különbségeket is feltételeznek. De felvethető az a probléma is, hogy a kevéssé fejlett megyékben, régiókban, hiába van felkészült munkaerő, ha az, megfelelő munkahelyek hiányában, elvándorol. Ezt pusztán gazdasági érdekekből kiindulva jó megoldásnak szokták gondolni, hiszen ha nem is 
otthon, de esetleg az ország más területén talál megfelelő munkát az illető szakember, akkor azzal is hozzájárul az országos teljesítmény növekedéséhez. Azonban az életminősége, akár a hosszú utazás, akár a munkásszálláson tartózkodás miatt nyilvánvalóan romlik. Arra is gondolni kell továbbá, hogy a hátrahagyott közösség gyengül, elöregedik, elszegényedik, ami hosszabb távon nemcsak helyi, hanem össztársadalmi problémákat is okoz, gyengítve a társadalmi tőkét.

Vizsgáljuk meg végül a regionális különbségek alakulását hosszabb távon, és ennek hatását az emberi fejlődésre. Az 5. táblázatban 2010 és 2019 között látjuk a régiók egy főre jutó GDP-értékének alakulását vásárlóerő-paritáson.

5. táblázat: Az egy fóre jutó GDP(vásárlóerö-paritáson) regionális értéke Magyarországon Forrás: a szerző szerkesztése az Eurostat 2021. július 14-ei adatai alapján

\begin{tabular}{|l|c|c|c|c|c|c|c|c|c|c|c|}
\hline $\begin{array}{l}\text { Ország, } \\
\text { fóváros, } \\
\text { régió }\end{array}$ & 2010 & 2011 & 2012 & 2013 & 2014 & 2015 & 2016 & 2017 & 2018 & 2019 & $\begin{array}{l}\text { Változás } \\
2010 \text {-ről } \\
2019 \text {-re } \\
\text { (euro/fó) }\end{array}$ \\
\hline Magyarország & 16400 & 17100 & 17100 & 17700 & 18400 & 19200 & 19400 & 20200 & 21600 & 22800 & +6400 \\
\hline Budapest & 35900 & 37200 & 37300 & 37300 & 38200 & 38500 & 39000 & 41200 & 43800 & 47100 & +11200 \\
\hline Pest megye & 14400 & 14500 & 14200 & 15000 & 15400 & 16100 & 15800 & 16000 & 17000 & 18200 & +3800 \\
\hline $\begin{array}{l}\text { Közép- } \\
\text { Dunántúl }\end{array}$ & 14200 & 15100 & 15000 & 15900 & 16600 & 18100 & 18400 & 18900 & 20100 & 21000 & +6800 \\
\hline $\begin{array}{l}\text { Nyugat- } \\
\text { Dunántúl }\end{array}$ & 16800 & 17500 & 17500 & 18100 & 19500 & 20900 & 21100 & 21200 & 22000 & 22200 & +5400 \\
\hline Dél-Dunántúl & 11100 & 11500 & 11700 & 12100 & 12100 & 12800 & 13000 & 13700 & 14900 & 15700 & +4600 \\
\hline $\begin{array}{l}\text { Észak- } \\
\text { Magyarország }\end{array}$ & 9800 & 10200 & 10100 & 10900 & 11500 & 12800 & 12900 & 14000 & 14900 & 15200 & +5400 \\
\hline Észak-Alföld & 10400 & 11200 & 11100 & 11300 & 11800 & 12300 & 12200 & 13000 & 13900 & 14800 & +4400 \\
\hline Dél-Alföld & 10900 & 11600 & 11800 & 12500 & 13000 & 14000 & 13900 & 14500 & 15800 & 16600 & +5700 \\
\hline EU27-átlag & 24900 & 25600 & 25700 & 26000 & 26600 & 27500 & 28200 & 29300 & 30200 & 31200 & +6300 \\
\hline
\end{tabular}

Az egy főre jutó GDP-érték idősoros alakulásánál először is azt látjuk, hogy Magyarországon a mutató értékének növekedése az EU-s átlag növekedésével együtt halad. Ebből azt a következtetést lehet levonni, hogy ha egyforma sebességgel haladunk, akkor az alacsonyabb szintről való indulás miatt kicsi az EU-s átlagérték gyors elérésnek esélye: 2010-ről 2019-re csupán 7 százalékponttal kerültünk közelebb az EU-s átlaghoz. Viszont, ha a fövárost nézzük, akkor azt látjuk, hogy minden egyes évben jelentősen meghaladja az itt keletkező egy főre jutó GDP az EU27 átlagát. Az ellentmondás okát a régiók lemaradásában kell keresnünk. Míg Budapest 2010-ről 2019-re 11200 euróval növelte az egy főre jutó GDP-je értékét, addig egyetlen kivétellel valamennyi magyar régió növekményértéke alacsonyabb, mint az EU-s átlag. (A kivétel Közép-Dunántúl, a +6800-as értékkel.) Ez azt jelenti, hogy Budapest és a régiók fejlődésénél nem a felzárkózás, hanem a fejlettségi különbségek növekedése látható. 
Érdekes Pest megye rossz pozíciója, amely annak a következménye, hogy korábban a Közép-Magyarország régióban együtt volt Budapesttel, és akkor a fejlesztési források döntő hányada Budapestre és nem Pest megyébe került. Már a közép-magyarországi régió létrehozásának oka is az volt, hogy Budapest hozzájuthasson az EU-s fejlesztési forrásokhoz, amelyekhez kiváló gazdasági adatai miatt egyedül nem juthatott hozzá. Pest megyével együtt azonban már annyira alacsony lett az egy főre jutó GDP-érték, hogy a létrehozott közép-magyarországi régió jogosult lett az EU-s támogatásra.

Összességében az adatokból levonhatjuk azt a következtetést, hogy a nagy regionális különbségek rontják a kevéssé fejlett régiókban élők emberi fejlődési lehetőségeit. Nyilván sokkal nagyobb esélye van egy átlag budapestinek az emberi fejlődésre, mint egy átlag észak-alföldinek vagy észak-magyarországinak. Ezt bizonyította a korábban említett Európai Társadalmi Haladás index tanulmány is, amikor rámutat arra, hogy Magyarország legkevéssé fejlett régióiban az alap- és magasabb szintủ tudáshoz jutási lehetőségek indexe rendkívül alacsony. Megjegyzendő, hogy a magasabb szintü tudáshoz jutás nemcsak az egyetemi képzésben, hanem a felnőttképzésben való részvételt is magában foglalja. A 6. táblázat az Európai Társadalmi Haladás index elemzés legfontosabb megállapításait foglalja össze.

6. táblázat: Regionális társadalmi fejlettségi adatok(0-100)

Forrás: European Commission (2020): i. m.

\begin{tabular}{|l|c|l|c|c|c|c|}
\hline Régiók & $\begin{array}{l}\text { Általános } \\
\text { helyezés }\end{array}$ & $\begin{array}{l}\text { Alapvető } \\
\text { emberi } \\
\text { szükségletek }\end{array}$ & $\begin{array}{l}\text { A jól-lét } \\
\text { alapjai }\end{array}$ & $\begin{array}{l}\text { Lehetö- } \\
\text { ségek }\end{array}$ & $\begin{array}{l}\text { Helyezés } \\
\text { a 242 régió } \\
\text { között }\end{array}$ & $\begin{array}{l}\text { Fejlettségi } \\
\text { szakasz } \\
(1-5)\end{array}$ \\
\hline EU-átlag & 66,7 & 80,0 & 63,9 & 57,5 & - & - \\
\hline Budapest & 63,6 & 80,8 & 56,3 & 55,3 & 155 & 5 \\
\hline Pest & 59,4 & 79,9 & 56,5 & 44,3 & 193 & 2 \\
\hline Nyugat-Dunántúl & 60,3 & 82,5 & 56,4 & 44,9 & 184 & 2 \\
\hline Közép-Dunántúl & 59,7 & 81,2 & 54,7 & 45,8 & 190 & 2 \\
\hline Dél-Dunántúl & 55,9 & 75,7 & 51,1 & 43,2 & 210 & 1 \\
\hline Észak-Magyarország & 50,9 & 69,4 & 46,8 & 38,3 & 228 & 1 \\
\hline Észak-Alföld & 54,2 & 73,9 & 50,0 & 41,1 & 220 & 1 \\
\hline Dél-Alföld & 56,8 & 75,5 & 52,2 & 44,9 & 206 & 2 \\
\hline
\end{tabular}

\begin{tabular}{|l|c|c|}
\hline \multirow{2}{*}{ Régiók } & Alapszintű & Magasabb szintü \\
\cline { 2 - 3 } & \multicolumn{2}{|c|}{ tudáshoz való hozzáférés } \\
\hline EU-átlag & 73,9 & 57,1 \\
\hline Budapest & 83,4 & 72,3 \\
\hline Pest & 79,7 & 35,9 \\
\hline Nyugat-Dunántúl & 76,1 & 32,7 \\
\hline Közép-Dunántúl & 66,7 & 31,5 \\
\hline Dél-Dunántúl & 76,1 & 32,7 \\
\hline Észak-Magyarország & 54,6 & 29,4 \\
\hline Észak-Alföld & 62,5 & 36,8 \\
\hline Dél-Alföld & 71,8 & 37,9 \\
\hline
\end{tabular}


A 6. táblázat bizonyítja, hogy az egy főre jutó GDP-vel mért gazdasági fejlettségben elmaradt régiók az emberi fejlettség minden területén le vannak szakadva Budapesttől. A jól-lét alapjai mutatók közül kiemelt alapszintủ tudáshoz, és a lehetőségek mutatók közül kiemelt magasabb szintű tudáshoz jutás lehetőségi szintje különösen alacsony. A táblázat 5. oszlopában láthatjuk, hogy a fejlettség tekintetében a magyar régiók hányadik helyen szerepelnek az EU 242 régiója között. A legroszszabb - 228. helyen - Észak-Magyarország van. Az utolsó oszlop pedig az általános fejlettséget mutatja egy 1-5-ös skálán. Azt látjuk, hogy a legmagasabb szintet egyedül Budapest éri el, három régió pedig a legalacsonyabb szinten van. Azonban a fejlettségben való lemaradás nem az alacsony egy före jutó GDP-nek tulajdonítható. A fejlettségi lemaradás oka az emberi fejlettségben, a tudásban való lemaradásban keresendő, ami egyben gátolja a gazdasági kibontakozást, a magasabb egy főre jutó GDP-érték elérését is.

Térjünk ki végül egy érdekes kérdésre, az innovatív cégek arányára. Ez egyszerre emberi fejlődési és gazdasági siker feltétel. Az innovatív cégek kínálják a fejlődés lehetőségét leginkább biztosító munkahelyeket. Az Eurostat legutóbbi, 2018. évi adatai szerint a legalább tíz fót foglalkoztató cégek közül Magyarországon csupán 287\% tekinthető innovatívnak. Ausztriában ez az érték 62,6\%. Az EU-s átlag 50,3\%. A magyar érték a 27 tagállam között a 25. Különösen meglepő, hogy a jelentős külföldi tőkebefektetésủ feldolgozóiparban sem jobb a helyzet: itt az innovatív cégek aránya Magyarországon 28,9\%, az osztrák érték 68,3\% és az EU-s átlag 54\%. Megjegyzendő, hogy vannak innovatívabb ágazatok is. Például az infokummikációs területen a cégek 51,5\%-a innovatív Magyarországon. Igaz, az osztrák érték 83,9\%, az EU-s átlag 69\%. Az adatokat az 1. ábrán foglaljuk össze.

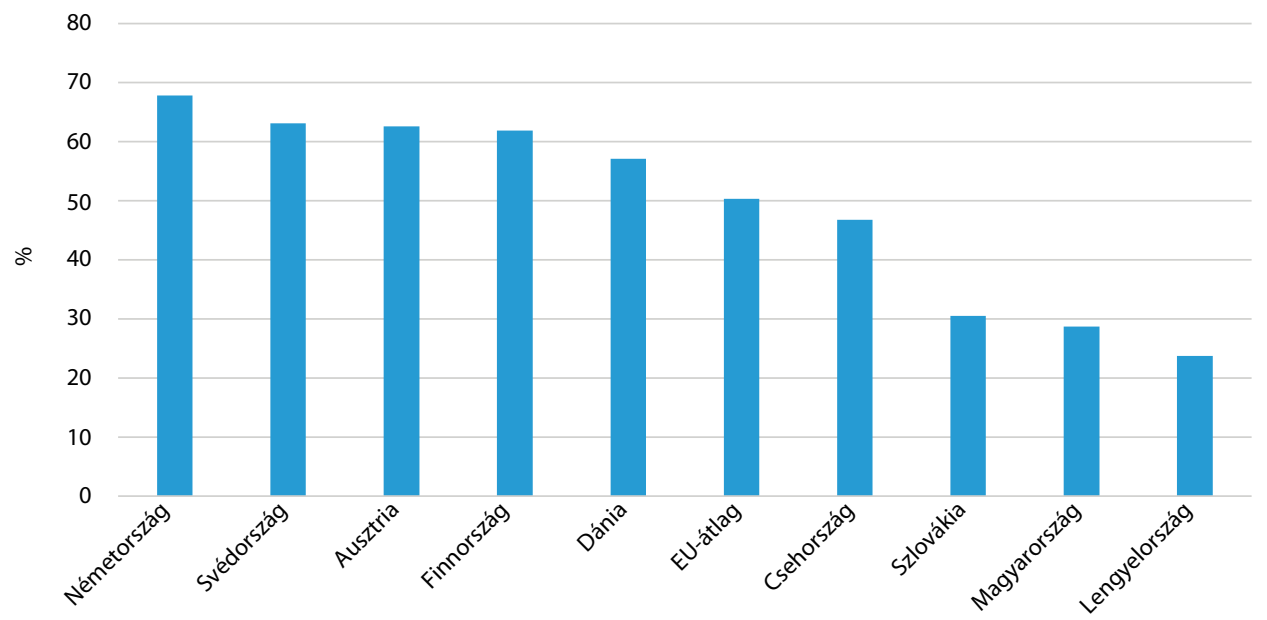

1. ábra: Az innovativ cégek aránya a legalább tíz fót foglalkoztató cégek között (2016-2018-as idöszak), \%

Forrás: Eurostat: Community Innovation Survey (2021. január 15.). 
Megemlíthető, hogy az innovatív cégek aránya szoros kapcsolatban van a gazdasági fejlettséget mérő versenyképességgel. Jellemzően a sok innovatív céggel rendelkező országok a versenyképességi lista elején vannak.

A módszertan kapcsán azonban fel kell figyelnünk egy hiányosságra. A felmérés csupán a legalább tíz főt foglalkoztató cégek körében történt. Nagyon valószínű azonban, hogy a tíz fő alatt foglalkoztató mikrocégek között sok az innovatív, és ezekről az Eurostat elemzése nem vesz tudomást.

\section{Nemzetközi fejlettségi elemzések: az emberi fejlettség humán mutatói}

Az emberi fejlettség általános, ENSZ-tanulmányokban szereplő HDI-mutatón alapuló méréséről már volt szó. Most nézzünk meg nemzetközi összehasonlításban néhány olyan fontos mutatót, amelyek segítségével a magyar helyzetet, nemzetközi kitekintésben, objektív adatok alapján lehet értékelni. Ahol ez az adat rendelkezésre áll, ott a regionális különbségekre is kitérünk. Természetesen további mutatókat is lehetne elemezni, de a gazdasági és humán fejlettség kapcsolatrendszerét ezek a mutatók is jól megvilágítják bizonyítva, hogy az emberi fejlettség egyben a tartós gazdasági sikernek is feltétele. Az egyik ilyen fontos mutató a gyermekkori szegénység.

Az emberi fejlődést már korán megakasztja a gyermekkori szegénység. Az Európai Unió szegénységi veszélyben lévőknek tekinti:

- az alacsony foglalkoztatottságú vagy munkanélküli felnőttek családjában élőket. Alacsony foglalkoztatású az, aki egy adott időtartam alatt a munkaidő csupán 20\%-ában, vagy annál kevesebb időben dolgozott;

- azokat a gyermekeket, akiknek a szülei nagyon alacsony végzettségüek;

- az egyszülős családokban élőket.

A 2020. évi Eurostat szerint, ahogyan a 7. táblázatban látjuk, Magyarországon a 18 év alatti korcsoportban 21,7\% él a szegénység és kirekesztettség kockázatával. Ezzel a vizsgált 25 tagország között a középmezőnyben, a 13. helyen vagyunk. (Olaszországra és Îrországra nem áll adat rendelkezésre). Ez az érték jobb, mint az EU-s átlag, ami 24,2\%. Meglepő a magyarnál rosszabb német adat (25,1\%), ami rosszabb az EU-s átlagnál is.

A fiatalkori szegénység nagyon fontos mutató abban a tekintetben is, hogy ebből a helyzetből nehéz kitörni, és azok, akiknek ez nem sikerült, emberi lehetőségeik alatt fognak teljesíteni, amellyel nemcsak egyéni fejlődésük nem tud kiteljesedni, de a társadalmi értékteremtéshez való hozzájárulási képességük sem alakul ki.

Kapcsolódó téma a 18-24 éves korban az iskolát abbahagyók száma, illetve korcsoportos aránya. Azok, akik a képzést nem fejezik be, nehezen találnak munkát, mivel tudásuk alacsony szinten megreked. Az EU legfrissebb, 2021. júniusi adatai alapján, Magyarországon ez az arány magas, 2020-ban 12,1\%. Ezzel a 27 tagország között a 22. helyen vagyunk. A lista élén Horvátországot, Görögországot, Szlovéniát, Írországot és Lengyelországot találjuk, de a cseh pozíció is jó, a 10. Az EU-s átlag 9,9\%.

A 8. táblázatban néhány ország adatait látjuk három időpontban. 
7. táblázat: Szegénység és kirekesztettség kockázatával élők korcsoport szerint, 2020, (\%)

Forrás: a szerző szerkesztése az Eurostat 2021. november 4-ei adatai alapján

\begin{tabular}{|l|c|c|c|}
\hline \multirow{2}{*}{ Országok } & \multicolumn{2}{|l|}{$\begin{array}{l}\text { Az összes lakosság } \\
\text { arányában }\end{array}$} & \multicolumn{2}{|l|}{$\begin{array}{l}\text { A 18 évnél fiatalabbak } \\
\text { között }\end{array}$} & $\begin{array}{l}\text { A 18-64 éves } \\
\text { korcsoportban }\end{array}$ \\
\cline { 2 - 4 } & \multicolumn{3}{|c|}{$(\%)$} \\
\hline Magyarország & 19,4 & 21,7 & 18,4 \\
\hline Csehország & 11,5 & 12,9 & 9,8 \\
\hline Lengyelország & 17,0 & 16,1 & 16,6 \\
\hline Szlovákia & 13,8 & 18,4 & 12,9 \\
\hline Ausztria & 16,7 & 21,9 & 22,1 \\
\hline Németország & 22,5 & 25,1 & 19,6 \\
\hline Dánia & 16,8 & 13,5 & 16,8 \\
\hline Finnország & 15,9 & 14,5 & 17,6 \\
\hline Svédország & 17,7 & 20,2 & \\
\hline
\end{tabular}

8. táblázat: Korai iskolaelhagyás a 18-24 évesek körében, 2011, 2015, 2020, (\%)

Forrás: a szerző szerkesztése az Eurostat 2021. október 18-ai adatai alapján

\begin{tabular}{|l|r|r|r|r|}
\hline \multirow{2}{*}{ Országok } & 2011 & 2015 & 2020 & \multirow{2}{*}{ Változás 2011-röl } \\
\cline { 2 - 5 } & \multicolumn{3}{|c|}{$(\%)$} & 120 -ra \\
\hline Magyarország & 11,4 & 11,6 & 7,6 & $+0,7$ \\
\hline Csehország & 4,9 & 6,2 & 5,4 & $+2,7$ \\
\hline Lengyelország & 5,6 & 5,3 & 7,6 & $-0,2$ \\
\hline Szlovákia & 5,1 & 6,9 & 8,1 & $+2,5$ \\
\hline Ausztria & 8,5 & 7,3 & 10,1 & $-0,4$ \\
\hline Németország & 11,6 & 10,1 & 9,3 & $-0,5$ \\
\hline Dánia & 10,3 & 8,1 & 8,2 & $-1,0$ \\
\hline Finnország & 9,8 & 9,2 & 7,7 & $-1,6$ \\
\hline Svédország & 6,6 & 7,0 & 9,9 & $+1,1$ \\
\hline EU-átlag & 13,2 & 11 & $-3,3$ \\
\hline
\end{tabular}

A magyar érték mindhárom időpontban nagyon magas, és növekszik is. 2015-ben és 2020-ban már a legmagasabb. Az EU 27 országa között csak Bulgária, Spanyolország, Olaszország, Málta és Románia van mögöttünk. Jelentősen romlott a cseh érték, de még így is nagyon alacsony. Feltűnő a magas német érték is. Az EU-s átlag viszont a vizsgált időtartam alatt jelentősen javult.

Nagyon fontosak a regionális eltérések is. Az EU vizsgálja a városok és a vidék adatainak eltérését is. A vidékiek helyzete, az adatok szerint, még rosszabb. 
9. táblázat: Korai iskolaelhagyók a 18-24 éves vidékiek körében 2011, 2015, 2020, (\%)

Forrás: a szerző szerkesztése az Eurostat 2021. október 18-ai adatai alapján

\begin{tabular}{|l|c|c|c|c|}
\hline \multirow{2}{*}{ Országok } & 2011 & 2015 & 2020 & \multirow{2}{*}{$\begin{array}{l}\text { Változás 2011-röl } \\
\text { 201-re }\end{array}$} \\
\cline { 2 - 5 } & \multicolumn{3}{|c|}{ százalék } & $+4,3$ \\
\hline Magyarország & 14,2 & 15,9 & 18,5 & $+2,6$ \\
\hline Lengyehország & 5,1 & 5,5 & 7,7 & $-1,1$ \\
\hline Szlovákia & 7,0 & 6,1 & 5,9 & $+1,2$ \\
\hline Ausztria & 7,0 & 10,1 & 8,2 & $-0,6$ \\
\hline Németország & 5,9 & 4,2 & 5,3 & $-1,8$ \\
\hline Dánia & 10 & 8,3 & 8,2 & $-0,5$ \\
\hline Finnország & 13,5 & 11,3 & 13,0 & $+0,9$ \\
\hline Svédország & 10,3 & 11,2 & 11,2 & $+2,2$ \\
\hline EU-átlag & 6,7 & 8,2 & 8,9 & $-4,1$ \\
\hline
\end{tabular}

A 9. táblázatban azt látjuk, hogy e tekintetben jelentősen rontottuk pozícióinkat 2011-ről 2020-ra úgy, hogy közben minden vizsgált évben a magyar adat volt a legrosszabb. A magyar értéknél 2020-ban csak a bolgár, spanyol és a román érték roszszabb, vagyis a 24. helyen vagyunk. Az „általános vidék” megnevezés mellett vannak konkrét regionális adatok is. Ezeket látjuk a 2. ábrán.

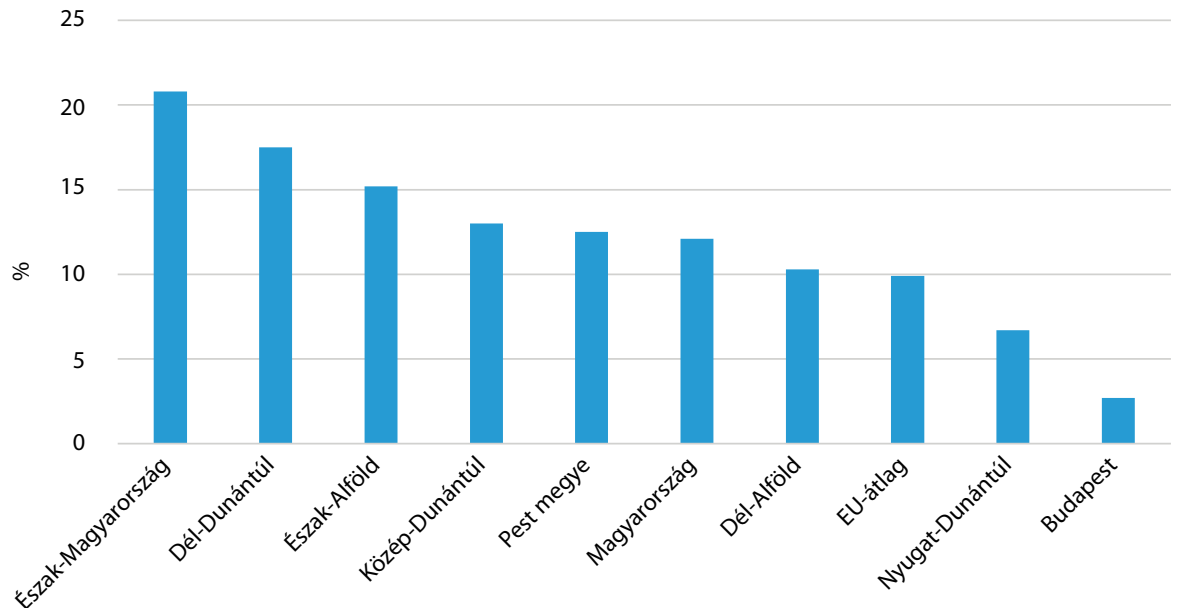

2. ábra: Korai iskolaelhagyók a 18-24 éves korcsoportban, regionálisan, 2020, (\%)

Forrás: a szerző szerkesztése az Eurostat 2021. október 18-ai adatai alapján

A korai iskolaelhagyók aránya a 18-24 éves korcsoportban nagyon magas Magyarországon általában, de a regionális különbségek még nagyobbak. A legjobb érték Budapesten van, a legrosszabb Észak-Magyarországon. A két régió közötti különbség 
18,1 százalékpont. Az iskolaelhagyók egy gazdaságilag is hátrányosabb térségben nehezen tudnak kitörni a fejletlenségi állapotból, ami nemcsak egyéni problémájuk, hanem országos gond is. Ha minden fiatal befejezné az iskolát és értékteremtő munkát végezhetne, azzal az egyéni fejlettségi szintje mellett az országos gazdasági fejlettségi szintet is javítani tudná.

Most nézzük meg az oktatási adatokat is különböző szempontok szerint. A 10. táblázatban a 25-34 éves, illetve a 25-74 éves korcsoportba tartozó felsőfokú végzettségủek arányát látjuk néhány országban 2011-ben és 2020-ban.

10. táblázat: Felsőfokú végzettségüek aránya a 25-74 éves és a 25-34 éves korcsoportban, 2011, 2020, (\%) Forrás: a szerző szerkesztése az Eurostat 2021. júniusi adatai alapján

\begin{tabular}{|l|c|c|c|c|c|c|}
\hline \multirow{3}{*}{ Ország } & \multicolumn{6}{|c|}{ Felsőfokú végzettségüek aránya } \\
\cline { 2 - 7 } & \multicolumn{7}{|c|}{$25-74$} & \multicolumn{7}{c|}{$25-34$} \\
\cline { 2 - 7 } & \multicolumn{7}{|c|}{ éves korcsoportban (\%) } \\
\cline { 2 - 7 } & 2011 & 2020 & Változás & 2011 & 2020 & Változás \\
\hline Magyarország & 20,0 & 26,0 & $+6,0$ & 28,2 & 30,7 & $+2,5$ \\
\hline Csehország & 17,3 & 22,7 & $+5,4$ & 25,1 & 33,0 & $+7,9$ \\
\hline Lengyelország & 22,0 & 29,7 & $+7,7$ & 39,0 & 42,4 & $+3,4$ \\
\hline Szlovákia & 17,7 & 24,9 & $+7,2$ & 25,5 & 39,0 & $+13,5$ \\
\hline Ausztria & 18,3 & 32,1 & $+13,8$ & 20,9 & 41,4 & $+20,5$ \\
\hline Németország & 26,5 & 30,5 & $+4,0$ & 27,6 & 35,1 & $+7,5$ \\
\hline EU-átlag & 23,7 & 30,6 & $+6,9$ & 33,0 & 40,5 & $+7,5$ \\
\hline
\end{tabular}

Az Eurostat 2021. júniusi adatai alapján a 25-34 éves korcsoportban felsőfokú végzettséggel rendelkezők aránya tekintetében Magyarország 2020-ban a 25. helyen van. Csak az olasz és a román adat rosszabb. Az élen Luxemburg, Írország, Ciprus, Litvánia és Hollandia van. Feltűnő az is, hogy 2011-ről 2020-ra a magyar adat javult a legkevésbé. A 25-74 éves korcsoport esetén a magyar adat jobb a cseh és a szlovák adatnál, de így is lényegesen rosszabb, mint az osztrák és a német, illetve az EU-s átlag érték. Nagyon fontosak azonban a regionális különbségek is. A 3. ábrán néhány város és magyar régiók adatait látjuk.

A 3. ábra azt bizonyítja, hogy a felsőfokú végzettségủek aránya regionálisan a 25-34 éves korcsoportban nagyon nagy eltéréseket mutat. Kiugrók a városi adatok. A vizsgált hat város között Budapest a 4. helyen van, megelőzve Bécset és Berlint. Óriási azonban a szakadék Budapest és a legalacsonyabb értéket elért ÉszakMagyarország között: 35 százalékpont. Ez ismét arra hívja fel a figyelmünket, hogy vidéken, ahogyan azt már a korábbi elemzések is megvilágították, sokkal nehezebb hozzájutni az emberi fejlődéshez szükséges magasabb szintű képzettséghez. Fontos mutató a végzettségi szerkezet is. A 11. táblázatban a különböző szintű képzettséggel rendelkezők arányát látjuk két időpontban hat ország esetén. 


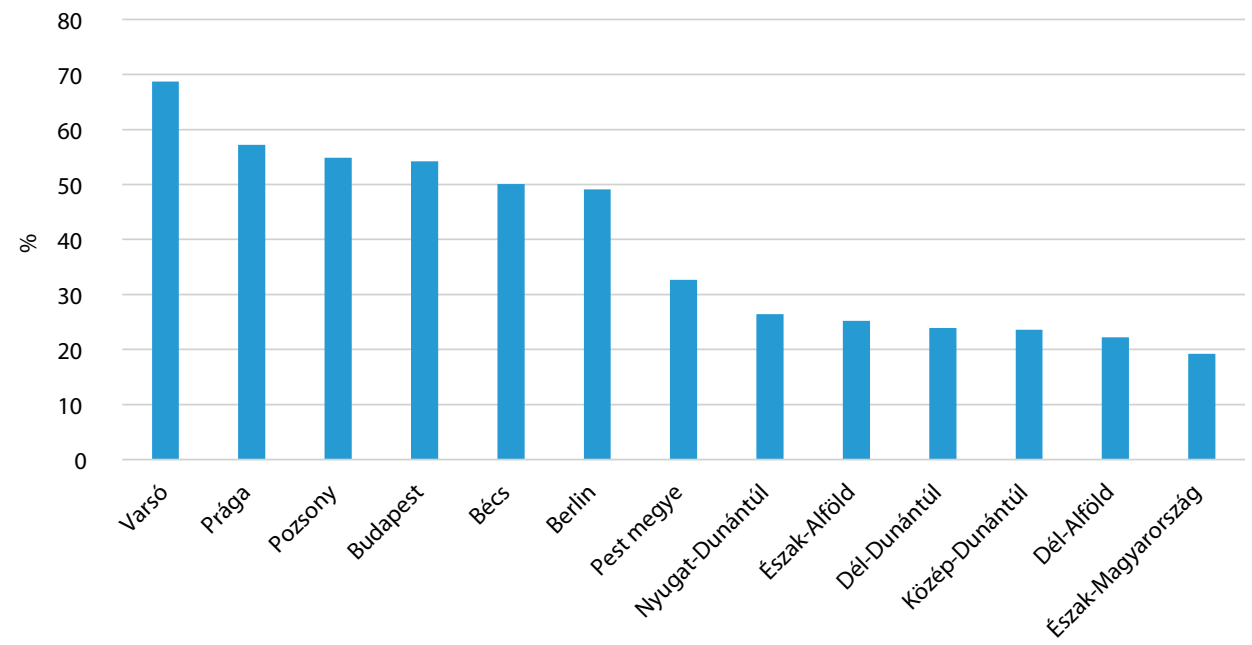

3. ábra: Felsőfokú végzettségüek a 25-34 éves korcsoportban NUTS 2 régiók szerint és néhány városban, 2020, (\%)

Forrás: a szerző szerkesztése az Eurostat 2021. november 3-ai adatai alapján

11. táblázat: A különbözö szintü képzettséggel rendelkezök aránya két korcsoportban, 2020, (\%)

Forrás: a szerzö szerkesztése az Eurostat 2021. júniusi adatai alapján

\begin{tabular}{|l|r|c|c|c|c|c|}
\hline \multirow{2}{*}{ Ország } & \multicolumn{3}{|c|}{$20-54$ év } & \multicolumn{3}{c|}{$55-74$ év } \\
\cline { 2 - 7 } & Alsó & Közép & Felső & Alsó & Közép & Felső \\
\cline { 2 - 7 } & \multicolumn{3}{|c|}{ szint } & \multicolumn{3}{c|}{ szint } \\
\hline Magyarország & 13,3 & 57,5 & 29,2 & 20,6 & 58,9 & 20,5 \\
\hline Csehország & 5,6 & 67,5 & 26,9 & 10,2 & 74,6 & 15,2 \\
\hline Lengyelország & 5,9 & 56,2 & 38,0 & 14,2 & 69,9 & 15,9 \\
\hline Szlovákia & 6,7 & 63,7 & 29,6 & 12,0 & 71,9 & 16,1 \\
\hline Ausztria & 12,7 & 50,1 & 37,2 & 22,1 & 54,8 & 23,1 \\
\hline Németország & 14,1 & 53,2 & 32,7 & 16,1 & 56,7 & 27,2 \\
\hline
\end{tabular}

A 11. táblázat adatai arra világítanak rá, hogy a vizsgált korcsoportokban Németország, illetve Ausztria után Magyarországon a legmagasabb az alacsony végzettségűek aránya. A középszintű végzettségủek esetén a cseh és a szlovák adat emelkedik ki mindkét korcsoportban. Az alacsony végzettségi szint gátolja az emberi fejlődést, sőt orvosi kutatások tanúsága szerint a várható élettartamra is kedvezőtlen hatást gyakorol. ${ }^{17}$

A 12. táblázatban kiemelve mutatjuk be az alacsony képzettségűek arányát két másik korcsoport esetén nemzetközi összehasonlításban.

17 Vigu Raghupathi - Wullianallur Raghupathi: The Influence of Education on Health: An Empirical Assessment of OECD Countries for the Period 1995-2015. Archives of Public Health, 78. (2020), 20. 
12. táblázat: Alacsony végzettségüek aránya a 25-74 éves és a 25-34 éves korcsoportban, 2020, (\%) Forrás: a szerző szerkesztése az Eurostat 2021. júniusi adatai alapján

\begin{tabular}{|l|c|c|c|c|c|c|}
\hline \multirow{3}{*}{ Ország } & \multicolumn{6}{|c|}{ Alacsony végzettségűek aránya } \\
\cline { 2 - 7 } & \multicolumn{7}{|c|}{$25-74$} & \multicolumn{4}{c|}{$25-34$} \\
\cline { 2 - 7 } & \multicolumn{7}{|c|}{ éves korcsoportban (\%) } \\
\cline { 2 - 7 } & 2011 & 2020 & Változás & 2011 & 2020 & Változás \\
\hline Magyarország & 23,6 & 15,9 & $-7,7$ & 12,9 & 12,4 & $-0,4$ \\
\hline Csehország & 9,4 & 7,3 & $-2,1$ & 5,7 & 7,6 & $+1,9$ \\
\hline Lengyelország & 14,6 & 9,0 & $-5,6$ & 6,0 & 6,2 & $+0,2$ \\
\hline Szlovákia & 11,3 & 8,6 & $-2,7$ & 6,0 & 7,3 & $+1,3$ \\
\hline Ausztria & 20,3 & 16,1 & $-4,2$ & 12,0 & 10,9 & $-1,1$ \\
\hline Németország & 15,1 & 14,9 & $-0,2$ & 13,0 & 13,2 & $+0,2$ \\
\hline EU-átlag & 30,7 & 24,0 & $-6,7$ & 19,1 & 14,7 & $-4,4$ \\
\hline
\end{tabular}

Azt találjuk, hogy az alacsony végzettségűek aránya 2020-ban Magyarországon a második legmagasabb, igaz az EU-átlagnál alacsonyabb, és csökkenő tendenciát mutat. A 25-34 éves fiatal csoport esetén a 2020. évi 12,4\% a V4-ek között figyelmeztetően magas. Ezek az emberek még nagyon sokáig aktívak lesznek, ezért - főleg a robotizáció gyors terjedése miatt - a munkanélküliség fenyegeti őket, ha nem tanulnak tovább. A leggyorsabb lehetőség a felnőttképzésben való részvétel lenne.

De hogy állunk felnőttképzés tekintetében nemzetközi összehasonlításban, illetve regionálisan?

A 4. ábra szerint a felnőttképzésben részt vevők aránya Magyarországon nagyon alacsony. Ez óriási veszélyhelyzetet érzékeltet: a gyorsan változó környezetben, az új technológiák megjelenésével, aki nem képezi folyamatosan tovább magát, az elvesztheti a munkahelyét.

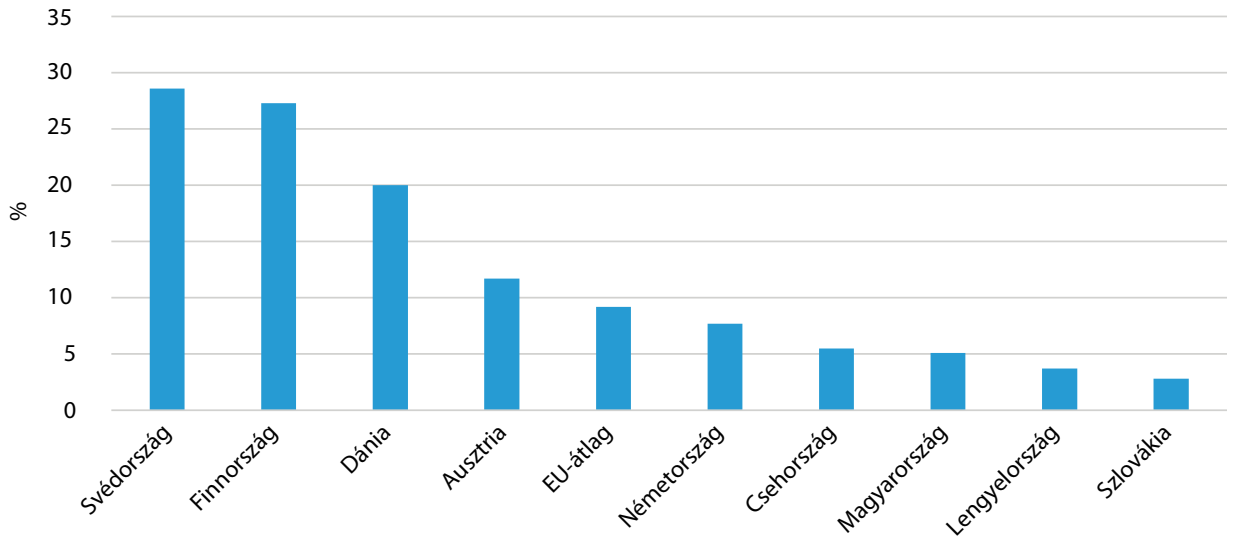

4. ábra: Oktatásban és tréningen részt vevők aránya a 25-64 éves korcsoportban, 2020, (\%)

Forrás: a szerző szerkesztése az Eurostat 2021. júniusi adatai alapján 
A felnőttképzésben való részvétel teszi lehetővé a tudásfelzárkózást, az emberi fejlődést az iskola elvégzése után. A magyar érték az EU 27 országa között a 20. helyre elég. Csak Szlovákiát, Lengyelországot, Ciprust, Görögországot, Horvátországot, Bulgáriát és Romániát előzzük meg.

Ha az alacsony végzettségűek magas arányára tekintünk, akkor ez az érték különösen veszélyesen alacsony, mivel nyilván nem járul hozzá a tudásbeli felzárkózáshoz, az emberi fejlődéshez. A regionális adatokat az 5. ábrán látjuk. A regionális adatok jelentős eltéréseket mutatnak még az alacsony országos átlagértékhez viszonyítva is.

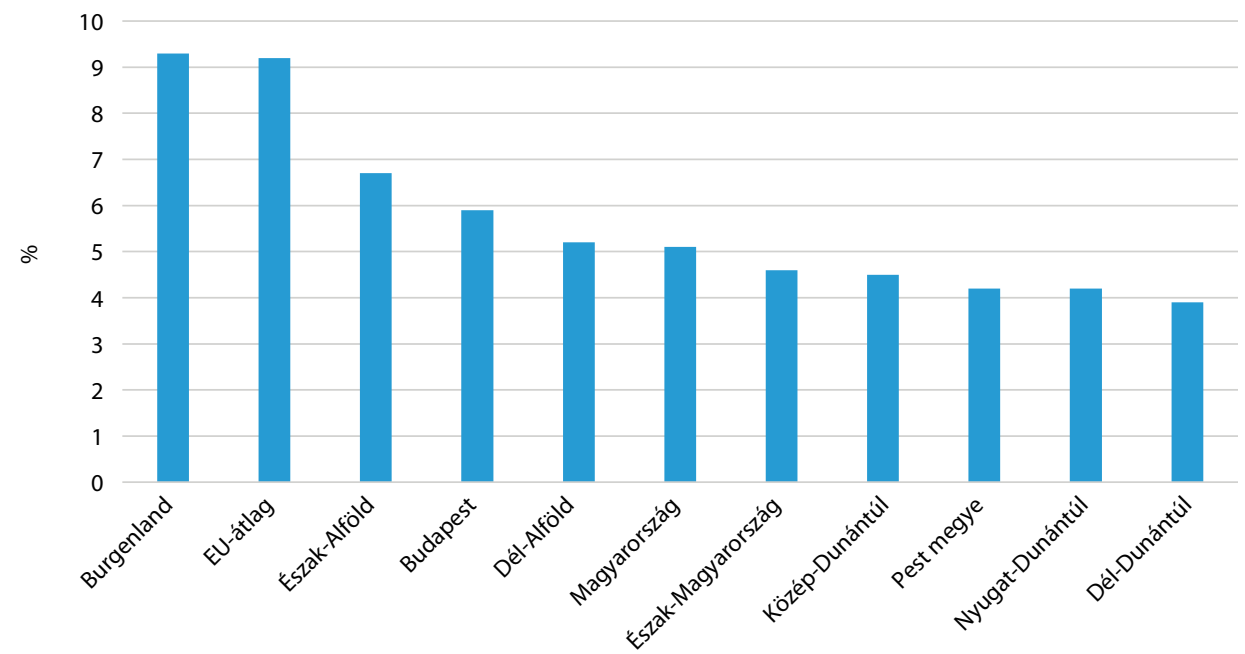

5. ábra: Oktatásban és képzésben részt vevők regionális aránya a 25-64 éves korcsoportban, 2021, (\%) Forrás: a szerző szerkesztése az Eurostat 2021. október 18-ai adatai alapján

A regionális adatok jelentős leszakadást mutatnak például Dél-Dunántúl esetén. De figyelemre érdemes, hogy a gazdaságilag fejlettnek tekintett Nyugat-Dunántúl adata is rosszabb, mint az átlagérték. Ennek az az egyik valószínü magyarázata, hogy az ott mủködő cégek összeszerelő üzemei növelik a GDP-t, igaz, abból a profit egy részét repatriálják, vagyis nem Magyarországon fektetik be. Viszont a repatriált profit is szerepel a GDP, illetve az egy före jutó GDP értékében. Ugyanakkor az összeszerelésre betanított munkaerő továbbképzése nem feltétlenül céges érdek, hiszen a „túlképzett” munkavállaló esetleg keresne más, nem összeszerelő munkalehetőséget. Érdemes még megemlíteni, hogy Burgenlandban, amely Ausztria legkevésbé fejlett régiója, a budapesti és a magyar országos átlagnál is többen vesznek részt felnőttképzésben.

\section{5. Összefoglalás és következtetések}

A cikk arra kívánt rámutatni, hogy egyrészt az emberi fejlődést és a tudás hasznosíthatóságát emberi jognak kellene tekinteni. Az emberi fejlődés elsősorban a tudáshoz 
jutást jelenti, amellyel nemcsak jobb életszínvonalat, hanem jobb életminőséget is el lehet érni. Azonban nem elég, ha a tudás megszerzésének lehetősége adott, hanem, ahogyan azt Maslow ${ }^{18}$ bizonyította, a tudás hasznosítása, az alkotás lehetősége is szükséges az emberi fejlődéshez. A nemzetközi elemzések azt is bizonyítják, hogy az emberi fejlődés nemcsak egyéni, hanem közösségi érdek is, hiszen a tanult ember több értéket tud teremteni a társadalom számára is. A tudáshasznosítás lehetőségei pedig a gazdaság szerkezetétől függenek, vagyis attól, hogy milyen szintű tudást igénylő munkahelyek állnak rendelkezésre. Ha nincs elegendő jó minőségű munkahely, akkor a jó szakemberek elhagyhatják az országot, ami nemzetivagyon-veszteség, hiszen ha otthon tudnának értéket teremteni, akkor azzal a gazdasági fejlődéshez otthon és nem külföldön járulnának hozzá. Másrészről, ha nincs elég jó minőségủ munkahely, akkor nincs elég ösztönzöttség az igényes képzésre sem. A tudáshasznosítás lehetőségeit befolyásolják továbbá a regionális gazdasági fejlettségi mutatók is. Ha egy régió nem kínál fejlődési lehetőséget a felkészült szakembereknek, akkor azok - ha nem külföldre mennek - ingázhatnak egy másik régióba. Ez gazdasági szempontból jó megoldásnak tűnhet, de emberi fejlődési szempontból kevéssé, hiszen az ingázás életminőség-rontó életforma, és a helyi közösség gyengítését is okozza. Az emberi fejlődést tehát közvetlenül befolyásolják a munkahelyi adottságok. Természetesen kulcskérdés a tudáshoz jutás is. Ezt eleve megnehezíti a gyermekkori szegénység és az iskola korai elhagyása. Az adatok azt mutatják, hogy Magyarországon nagyon nagyok a regionális különbségek, ami már indulásnál nehezíti a kevéssé fejlett régiókból származók emberi fejlődését. A felzárkózást segíthetné a felnőttképzés, amelyre az országos és a regionális mutatók is gyengék. De nálunk más vizsgált országokhoz képest alacsony a felsőfokú végzettségűek és magas az alacsony képzettségűek aránya, ami a gazdasági fejlődés fenntarthatóságát is nehezítheti. Magyarország sokat költ fizikai beruházásokra: útra, vasútra, épületekre, gépekre. A fejlődésnek azonban az emberi fejlődés, a tudás az első számú feltétele.

A megfogható gépi és egyéb beruházásokat, ha nem kísérik úgynevezett puha, nehezen mérhető, de a fizikainál fontosabb tudásberuházások és tudást hasznosító munkahelyeket teremtő beruházások, akkor a gyorsan változó, bizonytalan környezetben a magyar gazdaság fejlődése lelassulhat, fejlődési csapdahelyzetbe kerülhet. Azaz a gépi, technológiai beruházások mellett a humán fejlődés lehetőségét is meg kell teremteni mindenki számára, ahhoz hogy a valós, fenntartható gazdasági-társadalmi haladás megvalósulhasson. 


\section{Irodalomjegyzék}

Christoforou, Asimina: Social Capital and Human Development: An Empirical Investigation across European Countries. Journal of Institutional Economics, 6. (2010), 2. 191-214. Online: https:// doi.org/10.1017/S1744137409990324

European Commission: European Social Progress Index (2020). Online: https://ec.europa.eu/regional_policy/en/information/maps/social_progress2020

Eurostat: Community Innovation Survey (2021. január 15.). Online: https://ec.europa.eu/eurostat/ web/products-eurostat-news/-/ddn-20210115-2

Helliwell, John - Richard Layard - Jeffrey D. Sachs (szerk.): World Happiness Report. New York, Sustainable Development Solutions Network, 2019. Online: https://s3.amazonaws.com/happiness-report/2019/WHR19.pdf

Kunitz, Stephen, J.: Social Capital and Health. British Medical Bulletin, 69. (2004), 1. 61-73. Online: https://doi.org/10.1093/bmb/ldh015

Maslow, Abraham: A Theory of Human Motivation. Psychological Review, 50. (1943), 4. 370396. Online: https://doi.org/10.1037/h0054346

Ohno, Kenichi: Learning to Industrialize. From Given Growth to Policy-Aided Value Creation. London - New York, Routledge, 2013. Online: https://doi.org/10.4324/9780203085530

Pálfi Nóra: A külföldi munkavállalás hazai versenyképességre gyakorolt hatásainak vizsgálata. In Csath Magdolna (szerk.): Versenyképességi dilemmák a digitalizáció és robotizáció korában. Budapest, Dialóg Campus, 2020. 233-260.

Raghupathi, Vigu - Wullianallur Raghupathi: The Influence of Education on Health: An Empirical Assessment of OECD Countries for the Period 1995-2015. Archives of Public Health, 78. (2020), 20. Online: https://doi.org/10.1186/s13690-020-00402-5

Schultz, Theodore W.: The Economic Importance of Human Capital in Modernization. Education Economics, 1. (1993), 1. 13-19. Online: https://doi.org/10.1080/09645299300000003

Sen, Amartya: Development as Freedom. New York, Anchor Books, 2000.

UNDP: Human Development Report 2020. The next frontier: Human development and the Anthropocene. New York, (2020). Online: http://hdr.undp.org/sites/default/files/hdr2020.pdf

UNDP - OPHI: Global Multidimensional Poverty Index 2021. Unmasking disparities by ethnicity, caste and gender. (2021). Online: http://hdr.undp.org/sites/default/files/2021_mpi_report_ en.pdf

UNHR: Declaration on the Right to Development. UNGA Res. 41/128. (1986. december 4.). Online: www.ohchr.org/Documents/ProfessionalInterest/rtd.pdf

Uphoff, Eleonora P. - Kate E Pickett - Baltica Cabieses - Neil Small - John Wright: A Systematic Review of the Relationships between Social Capital and Socioeconomic Inequalities in Health: A Contribution to Understanding the Psychosocial Pathway of Health Inequalities. International Journal for Equity in Health, 12. (2013), 54. Online: https://doi.org/10.1186/1475-9276$12-54$

Zhao, Jing - Sejin Ha - Richard Widdows: The Influence of Social Capital on Knowledge Creation in Online Health Communities. Information Technology and Management, 17. (2015), 4. 311 321. Online: https://doi.org/10.1007/s10799-014-0211-3 